\title{
What Can We Learn from the Islamic Tradition About the Pandemic?
}

\section{Emine Öztürk}

Abstract

First of all, we must explain this, there is a big literature about pandemies in Islamic religious literature. So, there a lot of things we can learn about pandemy from Islamic literature. Once a day prophet Mohammed said that about pandemy, if there is a pandemy anybody doesn't go out form there, and if there is pandemy in anyplace outside don't go into that place untill pandemy stops. This verse of prophet Mohammed tells us everything about pandemy. Beacuse this verse is about isolation. And also prophet Mohammed says cleanliness is the half of belief. And also he says cleanliness comes from beleif. So there are a lot of things in Islamic literature about pandemy that we can learn. So, we hope that we can tell some important points about pandemy approcah of Islam. We hope we can do some contributes about this subject. Of course, this is not the last word about this subjcet but it is a word about thıs subject that we can learn some important points form Islamic literature. ${ }^{1}$

Keywords: Islamic tradition, Pandemic

\section{Introduction}

In dictionaries there are many words which are related with pandemic. First word which related with pandemic is epidemic; it means outbreak, contagious and epidemic. And the other word with pandemic is epidemiology; it means the branch of modern medicine which is related with incidence and distribution. Anda there are epidemic diseases some of them are flu, influenza, grippe, cold, commmon cold, mumps, parotitis, cholera, malaria, ague, jungle fever, intermittent fever, marsh fever, varicella, chicken pox, swine pox, plague, pestillence, Black Death, pest, fowl pest. But all of these epidemic diseases does not mean that it is impossible to counterwork the distribution of these diseases. But some of these diseases are nor only epidemic but they are also pandemic, likewise cholera, malaria, ague, jungle fever, intermittent fever, marsh fever, varicella, chicken pox, swine pox, plague, pestillence, Black Death, pest, fowl pest. The diseases like cholera, malaria, ague, jungle fever, intermittent fever, marsh fever, varicella, chicken pox, swine pox, plague, pestillence, Black Death, pest, fowl pest are not only distributed in one country, they are distributed allover the world. We must konw that pandemic means a disease which is distributed all over the world. So now Covid -19 as the othername Choronavirus is distributed all over world. So, Choronavirus is a pandemic.

During the history there are many pandemics have seen all over the world. For example plague, pestillence, Black Death, pest, fowl pest. The first pandemic which is emerged in Europe in sixth century is the Plague of Justinian, and the other is Black Death, which is emerged in Europe in 1347 wtih Genoeses' arrival by following the sea route in Italy, it has been moved to Europe. Ibn Khaldun says that one year later after 1347 I have lost my father beacuse of the Black Death in 1348.

That is why we transferred the word to Ibn Khaldun because he is a Muslim Sociologist but he lived in Europe when he was a child. This means that pandemic not only affects not only Europe but it also affects whole the world and also the IsLamic world and Muslims. The people and the scholars who are listenning to me now, I think they know everything about the History of Pandemic of Europe. But we have to see that, there are many places and nations and religions on the earth that must ask question about this subject? What are the other nations and religions are doing about pandemic?

Let's have look about the History of Pandemic in Islamic Tradition. "Because of the Plague of Justinian, in Constantinople six thousand people died in an day in sixth century. During the Anatolian Seljuks there are mnay pandemics have emerged because of the military expeditions, sieges and famine. Because the military expeditions, sieges and famine have caused the people to loose the resistances of their bodies. And then they got diseases. Under the reign of the First (I) Suleyman

\footnotetext{
${ }^{1}$ Prof.Dr., Kafkas University, Divinity Faculty; Head of Philosophy and Religious Sciences Department, ozturkemine25 @ gmail.com.
} 
Shah in 1078 during the four months sixth hundred thousand people have died. Duirng the first crusade and throughout the siege of Antakya in 1098100.000 people died only form the Frank's army. In the period when Melik Mohammed, the ruler of the Danishmend, ruled Malatya, there had been an epidemic which killed first of all poultry then at the begining little children, and after a lot of people. In the period of Mesut the First, in 1153, during the Chukurova expedition, under the reign of Kılıcarslan the second, in the Seljuks army, following the famine, a plague emerged in Syria, Iraq, Diyarbakır and Ahlat. Because of the plague the people were unable to bury the bodies. Duirng the reign of Alaeddin Keykubad after the famine which emerged 1244 in Malatya and 1259 in Syria. Anatolia during the Mongolian sieges a plague emerged because of famine in Mardin and Silvan and it caused a great destruction."

\section{Now by the time we have to ask this question}

How can Muslims deal with or overcome pandemic during historical pandemic processes? We can explain these two questions in several numeric answers:

First of all, there are verses from the Qur'an regarding cleaning and hygiene.

One of them is the verse of Maidah 6: Let's look, what the verse Maidah 6, tells us about celarness and hygen. "O you who have believed, when you rise to [perform] prayer, wash your faces and your forearms to the elbows and wipe over your heads and wash your feet to the ankles. And if you are in a state of janabah ${ }^{2}$, then purify yourselves. But if you are ill or on a journey or one of you comes from the place of relieving himself or you have contacted women and do not find water, then seek clean earth and wipe over your faces and hands with it. Allah does not intend to make difficulty for you, but $\mathrm{He}$ intends to purify you and complete His favor upon you that you may be grateful." 3

In this version, Allah tells us to take ablution and to be cleaned before the prayer to himself. And a Muslim have to ablution five times in a day. And a person who takes ablution in a day, he or she could not be dirty, beacuse he or she washes the parts of his or her body five times in day os he or she could not be dirty. Washing some parts of the body five times in a day give a person spaciousness and roominess and reprieve that person during all of the day. So this spaciousness, roominess and reprieve protects you from stress and viruses and also choronavirus.

2-Second iti is very important in Quran that the things people eat in the daily life must be clean, not only celan but also halal ${ }^{4}$. Maidah 88 is about the cleanliness of the things we eat. "And eat of what Allah has provided for you [which is] lawful and good. And fear Allah, in whom you are believers." ${ }^{5}$ And there are many other verses which tells us about cleanliness in Qur'an. ${ }^{6}$

There are 49 verses in Qur'an which tells about clear and halal food. And there are 2 verses in Quran about body cleanliness. ${ }^{7}$ So, cleanliness is very important in Islam.

3-And also prophet Mohammed has many hadiths about cleanliness. A few of them are these:

1 -"Cleanliness is the half of the faith."

\footnotetext{
${ }^{1}$ Bayat, Ali Haydar; History of Medicine, Merkezefendi Traditional Medicine Association, İstanbul, 2010, s.267.

${ }^{2}$ Literally, "distance." The state of one under obligation to perform ghusl (a complete bath) due to having had sexual intercourse or ejaculation.

35 /al-Maidah/88

${ }^{4}$ Halal means lawfull.

5 5/al-Maidah/88

${ }^{6}$ These verses are those. 2/al-Baqarah/57, 125, 168, 172, 222, 267; 4/an-Nisa/43,160; 5/Maidah/4,5,6,87,88,100; 6/al-An'am/145; 7/al-A'raf/31,32,82,157, 160; 8/al-Anfal/26,37,69; 10/Yunus/93, 11/Hud/78; 16/an-Nahl/3, 66,72, 97, 114; 17/al-Isra/70; 18/al-Kahf/19; 20/at-Taha/81; 22/al-Hajj/26,29; 23/al-Mu'minun/50,51; 24/anNur/26; 25/al-Furqan/48; 27/an-Naml/56; 38/as-Sa'd/29; 40/al-Mu'min/64; 45/al-Jathiyah/16; 47/alMohammed/15; 56/al-Vaqiah/79; 74/al-Muddaththir/4,5; 76/al-Insan/21; 91/ash-Shams/9.

${ }^{7}$ Look for these verses. The Qur'an English Meanings, Saheeh International, Jeddah, Abu'lqasım Publishing House,1997- al-Muntada al-Islamı- 2004.

${ }^{8}$ Müslim, Ebu'l-Hüseyin Müslimu'bnu'l-Haccac el-Kuşeyri en-Niysaburi, Sahihi Müslim, Verification: Muhammed Fuâd Abdülbâkî, Beyrut: Dâru İhyai't-Türasi'l-Arabi, 1956, Lustration, I.
} 
2-"Allah is clean, accepts only clean. Whatever Allah commanded his prophets, he commanded the beleivers. Allah Almighty to the Prophets, "O prophets eat things that are clean and halal, do good and usefull work. And to the beleivers "Oo you who beleive, Eat one of the clean ones of the susters we gave you."1

3-"When a Muslim or beleiver takes ablution, while he is washing his face, his sins which he done with his face are poured with ablution water(or the last drop of water). When he washes his hands, the sins he commits with his hands are poured with ablution water(or the last drop of water). When he washes his feet, his sins which he has done with his feet flow through the ablution water (or the last drops of the water). Finally he will be completely free from all of his sins."2

4-"When one of you will fast, open it with dates; because dates are abundant. If he cannot find dates; open his fast with water; because his water is clean." 3

5-"If a person takes ablution, and if he is cleaned as much as he can, and he crawls from his own special smell or the fregnance in his house and leaves his house as this way; does not enter between two people, then he performs his obligatory prayer on him; if he is silent and listens to him while reading the sermon, their sins from Friday are forgiven." 4

6-" If a person is cleaned beautifully in his house; and then goes to one of the houses of Allah; each of these steps will wipe out a sin; and the other step raises him one another degree." 5

7-“Whoever gets ablution on Friday; what it is good; especially he gets big ablution."6

8-"If I had not worried about putting my ummah (or my people) into trouble; I would have ordered them to clean their teeth with miswak every time of prayer."7

We can take these massages below about daily cleanliness from all these hadiths.

Cleanliness is the half of the faith.

Allah is clean, accepts only clean.

Ablution cleans the person in terms of two size; one size is material, and the other is spiritual.

Water is clean, poen your fast with water.

Taking ablution cleans you in terms of two size; one size is material, and the other is spiritual.

Cleaning beautifully and going the house of Allah; saves you form all sins, and gives you spiritual degrees.

Celaning your teeth gives you Lord's consent.

And also, Muslims cope wtih or overcome with the pandemic also by quarantine.

And also, there are some hadiths of Prophet Mohammed about quarantine in basic Hadith Books. Before we look to these quarantine hadiths, let's learn about what is quarantine and then let's look at these hadiths about quarantine. Quarantine is not to enter the place, human beings and animals, where the infectus disease is seen from outside, and also human beings and animals, is not to go out from inside, where the infectus disease is seen, to the outside. There is isolation in quarantine. The intact willnot come close to the sick. So protection is essential. The quarantine applicaiton started with the advice applicaitons of the Prophet Mohammed (peace be upon him). It has forbidden others from entering and leaving the areas where infectious diseases are seen. Here, the Prophet (peace be upon him) has revealed that the diseases are not destiny and not bad luck. He also stated that we should be protected from these diseases. It has been seen that quarantine

\footnotetext{
${ }^{1}$ Muslim, Alms, 65.

2 Muslim, Lustration, 32.

3 Tirmizî, Ebu İsa Muhammed bin İsa bin Sevre es-Sülemi et-Tirmizi, Sünen-i Tirmizi, Verification: Ahmad

Mohammed Shakir, al-Maktabatul-Islamiyya, Alms, 26.

${ }^{4}$ Buhârî, Ebû Abdillâh Muhammed b. İsmâîl b. İbrâhîm Cu'fî Buhârî, Sahih-i Buhari, Kahire: Mustafa el-Babi el-

Halebi, 1953, Friday Prayer; 6, 19.

${ }^{5}$ Müslim, Masajid, 282.

6Tirmizî, Friday Prayer; 5.

${ }^{7}$ Buhârî, Friday Prayer; 8; Hope, 9; Fast, 27; Müslim, Lustration, 42.
} 
is mandatory in other parts of the world and has been started to be applied partially from the 14th century. Millions of people have died from infectious diseases. Quarantine started to be implemented by the World Health Organization since 1952.

Now let's look at these hadiths about quarantine. One of these Hadiths is this.

1-"In the history of Islam, when Majesty Omar (God bless him) was the caliph, he was going to Damascus. It was learned that there was a Black Death or plague disease in Damascus. Abdurrahman bin Avf said to caliph Omar (God bless him) : Prophet Mohammed said that "Do not enter the place where there is plague or Black Death. If plague is seen in your place, do not leave there." At that time, Abu Ubeyde said to caliph Omar: "O Omar! Are you running away from Allah's accident?"

Upon saying:

- "Yes. I escape and beg from Allah's accident to his destiny." He gave the answer to Abu Ubeyde."2

And the second hadith is on the below.

2-"If you hear that there is a plague somewhere, do not go there. If plague occurs at your location, do not leave."3

And the third hadith is on the below:

3- "There is a danger of being close to the disease."4

And the fourth hadith is on the below:

4- "Do not put the sick animal next to the flat, which is solid."

And the fifth hadith is on the below:

5- "Escape from leper as if escaping from the lion."6

And the sixth hadith is on the below:

6- "Also about allegiance from the Sakif tribe coming to Madinah a leper in a delegation

When he heard that he was there, he said, "Come back, We accepted your allegiance." is known to have sent."?

As, it is understood from al these hadiths, Prophet Mohammed is the only and the first person, who advises quarantine and isolation against pandemic in the history. Now let's look at the history of Islamic Medicine. And then let's look about what did Muslim doctors except cleenliness and aquarantine in Islamic history against pandemies during the Islamic Medicine History.

"Islamic civilization revived the classical culture that descended almost everywhere in medieval times. The reason for this success is that it can adapt existing cultures and is open to all kinds of ideas. For example, more VIII. In the 19th century, Câbîr wrote that the universe would tear the secret of the glaze, create living and inanimate beings, at least this is theoretically possible. It is very important that he can express them at that time. Without being influenced by any religious official opinion, the knowledge has spread thanks to scholars who can conduct research in various languages. Thus, Islamic science gathered the sciences of the ancient world in itself, translated its works, added new information and transferred them to the West with the will that triumphed on the courage and a strong sense of self while choosing the useful elements."

\footnotetext{
${ }^{1}$ Ahmad b. Hanbal - Şuayib el-Arneut, Musnad; Müessesetu'r-risale, 1999, 42: 53 (25118); Ebu Dâvud, Süleyman b. el-Eş'as, Sünenu Ebî Dâvud, İstanbul: Çağrı Yayınları, 1992, "Funerals”, 6.

2 İbn Kesîr, Ebü'l-Fidâ' İmâdüddîn İsmâîl b. Şihâbiddîn Ömer b. Kesir el-Kureyși ed-Dımeșki. al-Bidâyah va'n-nihâyah, Verification: Abdullah b. Abdulmuhsin et-Türki, Dâru'l- Hicre, 1998.c. X, s. 172.

${ }^{3}$ Ahmad b. Hanbal, Musnad, 42 : 53 (25118); Ebu Dâvud, "Funerals", 6.

${ }^{4}$ Ebu Davud, Sünen,3923.

${ }^{5}$ Buhari, Medicine, 31.

${ }^{6}$ Buhari, Medicine, 16.

${ }^{7}$ Ibn Mace, Ebu Abdullah Muhammed bin Yezid er-Rebei el-Kazvini İbn Mace, Sünen, Delhi: Matbaatu'n-Nizami, 1905; Medicine, 44.

${ }^{8}$ Bayat, History of Medicine, s.205.
} 
"The art of medicine, which is among the primary sciences (ulûmu'l-evâil) in Islamic culture, has developed in a short time. This movement took place in 2 stages:"1

"Accepting Period: With the encouragement of religion, the ancient culture and medicine on which Islamic geography rested were adopted; Hospital and medical education in Cündişapur was taken as an example; Scientific books of Ancient Greek and Indian medicine were translated in Beytü'l-Hikmah, which was established in Baghdad during the Abbasid period, within 200 years."2

"Creative Period: After learning ancient medicine information, with new medical knowledge obtained through observations and experiments, XII. In the 19th century, as the science historian Hartner put it, the idea of reliance on medieval fashion old authorities that would endanger the thought was abandoned, and the originality of scientific thought reached an unprecedented point until then. In this creative period, Muslim physicians dominated the world of scientific medicine for 600 years with their books. It has become. It is necessary to examine the institutions that reveal this brand new understanding of science and medicine in more detail."3

\section{Gundeshapur Medical School And Commencement of Medical Translations}

"The city of Gundeshapur, founded by the Persian Sassanid ruler of Iran, [241-73] on the road connecting Sûs and Hemedan, has long been recognized as the science and art center of the region. Gundeshapur, where a large group of artists, scholars and workers in Syria, together with the prisoners, was placed in the war where the First Emperor destroyed the Roman emperor Valerian. It was also a shelter for the Nesturians expelled from Anatolia. Husrev I (Anûşirvân) [531-79] sent a delegation of culture to India and brought many Indian scholars to Gundeshapur. Doctors named Berziye and Sencehl, whose books were later translated into Arabic in Beytü'l-Hikmah, are two of them. Again in his period, the New Platonic teachers of Athens were accepted to this city after the academy was closed in 529 . Thanks to the school founded by Husrev I, the city has become the science center of the region. Large physician families, who grew up in this region where Greek-Indian-Iranian medical knowledge was synthesized, have contributed greatly to the advancement of scientific medicine in Islamic civilization with the medicine and the medicine books they translated. After Iran came under Muslim rule in 638 , the scientific institutions here were not touched, and scientists -especially physicians- were respected by the Abbasid dynasty, and physicians trained in Gundeshapur worked in the palace, and scientists in translation schools."

"At the time of Islam, there were powerful science and philosophy centers in the north of Arabia. Arab armies encountered a developed medical school and hospital [638] in Gundeshapur, and the scientific legacy of Ancient Egypt and Greek civilization in Alexandria, a major science and research center [642]. Also, Antakya and Edessa (Urfa) were important science centers." ${ }^{\text {}}$

"Buhtişû family, one of the physicians of Gundeshapur Hospital, for 4 generations (Curcîs bin Cibrâil [d. 769], Buhtişû bin Curcîs [d. 801], Cibrâil bin Buhtişû [d. 828], Buhtişû' bin Cibrâîl [d. 870]. On the other hand, he worked as a private doctor of the Baghdad palace and on the other hand he was engaged in translation works. Book translations from Greek to Pahlevi (ancient Persian), which started before Islam in Gundeshapur, Alexandria and Edessa, continued during the Umayyad period, [661-750], scattered from Greek and Pahlevi to Arabic."6

"The original translation period started in the first period of the Abbasid state [750-860] with Beytü'l Hikmah. Created by Caliph Mansur [754-74], Beytu'l Hikmah gained wide space and regular functioning in the time of his grandson Hârûn erReşîd [786-809]. became like that. The number of books collected in Beytü'l-Hikmah has reached a level that cannot be compared to anywhere else in the medieval world. Beytü'l Hikmah was later withdrawn from the history scene, leaving its place to the daru'l-ilm/daru'l-kutubs established in Mosul, Bust, Basra, Baghdad, Shiraz, Rey, Cairo and Kayravan."

"Medical studies in Beytü'l-Hikmah started with the coming of Baghdad with many scientific works of Indian physicians brought by caliph Mansur from Gundeshapur. IX. In the early part of the century, John bin Masselay, Jibrâil bin Buhtişû

\footnotetext{
${ }^{1}$ Bayat, History of Medicine, s.205.

${ }^{2}$ Bayat, History of Medicine, s.205.

${ }^{3}$ Bayat, History of Medicine, s.205.

${ }^{4}$ Bayat, History of Medicine, s.205-206.

${ }^{5}$ Bayat, History of Medicine, s. 206.

${ }^{6}$ Bayat, History of Medicine, s. 206.

${ }^{7}$ Bayat, History of Medicine, s. 206-207.
} 
'and Huneyn bin İshâk translated many medical works in Beytü'l-Hikmah with the suggestions of physicians from Gundeshapur. Indian physician Mankah and Sâlih bin Bahle, who healed Hârûn er-Reşîd's uncle, carried the Indian medicine to Baghdad palace."1

"He brought books from the important cities of Byzantium and asked the Cypriot judge to send the books in his hand as war compensation; Mutasim brought the valuable books [838] to Baghdad under the conquest of Ankara and Amorium. Sometimes it was necessary to travel long to find a book. Huneyn bin Ishaq stated that Galenus traveled Iraq, Syria, Palestine and Egypt for his book about the pulse and finally found it in Damascus. Collected works, Hunayn bin İshâk [d. 873], his son İshâk bin Hunayn, al-Kindî [d. 870], Shabbin bin Kurra and Kosta bin Luka [d. 912] has been translated by people who know Arabic-Greek-Syriac very well. The translators were paid by the weight of the books. Those who wrote on thick papers and large letters for heavy suffering were complained by the treasury minister, and the caliph ordered that the treasure will not be impoverished by the gold given to scientists and spent on the science path."2

"During this period of 200 years, Greek such as Hippocrates, Galenus, Ephesus Rufus, Dioskorides, Oribasius; The works of Indian physicians such as Susruta, Caraka, Vagbhata, Zantâh and Canakya were transferred to 37 Arabic. 64 works of Galenus, 13 of Hippocrates, and 20 of Rufus of Ephesus were translated. Thus, the loss of ancient medicine books was prevented and it was provided to be read in very remote areas. Muslim physicians who absorb the medical heritage of antiquity, adding their experiments, observations, knowledge and experience to the books, original works. They have become the leader of medicine in the East and West for nearly 600 years throughout the Middle Ages with the medical education they have provided in the health institutions they have established." 3

Some of Hippocrates's Works Translated into Arabic ${ }^{4}$

"Although it is mentioned in some sources that the first Muslim hospital was built in 707 by the Umayyad Caliph Velid bin Abdülmelik in Damascus, this is a structure that was modeled by the Byzantine nosocomium and was established as a shelter for the lepers and the blind. The first full-fledged Islamic hospital was established in Baghdad in around 800, during the Abbasid period, by Hârûn ar-Raşîd and was managed by one of the Gundeshapur, physicians, Cibrâll bin Buhtişû. This hospital has set an example for other hospitals to be established in Baghdad and other major Islamic cities. IX-XVII. Between the centuries, many dharüşşifas were established in a wide geography from Andalusia to India, in Umayyads, Abbasids, Seljukies, Mamlukies, Ilkhanids, Timurids, Aqquyunlus and Ottoman countries."5

"Among the first İslamic hospitals we can count, these are the below,

1-the haospital which is built in Baghdad by Harun ar-Raşid and Bermekids;

2-the hospital which is built by the bridesmaid of the caliph Mutavakkil [847-61] Turk al-Fath bin Khakan [d. 861] in Cairo under the name of Mâristânü'l-Magafîr;

3-the hospital which is built in Cairo in 874 by Ahmad bin Tolun who is one of the Tolunids, 4-the hospital which is built by Abubakir Mohammed bin Togac(842-942) who is one of the Ikhshidies in Eygpt,

5-the hospital which is built by Bedrü'l-Mutaddîd Gulâm in in Baghdad in 902;

6-the hospital which is built by caliph Mukhtadir in (908-32) in the door of the Damascus;

7-the hospital which is built by vizier Ali ibn al-Furat (d.924) in Baghdad in Dâru'l Mufaddala,

8- the hospital which is built in Baghdad in 940 by Amîr Ebû'l-Hasan Baghâm et-Türkî who is one of the commanders of the caliph al-Muktefî (902-08),

9-the hospital which is built in Baghdad in 966 by Mu'izzüddevle who is one of the Buvayhid kings;

\footnotetext{
${ }^{1}$ Bayat, History of Medicine, s. 207.

2 Bayat, History of Medicine, s. 207.

${ }^{3}$ Bayat, History of Medicine, s. 207.

${ }^{4}$ Bayat, History of Medicine, s. 208.

${ }^{5}$ Bayat, History of Medicine, s. 209.
} 
10- the hospital which is built in Baghdad in 982 by Adûduddevle who is one of the emirate of the emirates of Buvayhids which was named The Bimaristan of Adudi;

11- the hospitals which are built in Basra by a slave who is borught from Anatolia in the period of caliph Nasr li-Dinillah (1180-1225);

12- the hospital which is built in 957 by the one of the kings of Ikhshids Kafur which is named Maristani Kafuri,

13- and last hospital which is opened by Sinan bin Sabit who is the surgeon general of caliph Mukhtadir which is named the Bimaristan of Sayyidah."1

"Other than these; it is known that;

1-in X.th century there are 4 hospitals in Rey, Zerend, Isfahan, Marv and Nishapur;

2-in XI.th century there are 4 hospitals in Vasit(1022) and Mayyakafirin(1031);

3- in XII.th century there are 4 hospitals in Mosul, and 2 hispitals in Edessa; and one each in Nusaybin, Haleb and Hama."

And there are many hospitals in also Andalusia ${ }^{3}$ taht $w$ can not count them in here because of our reserach's volume. And let's look at some doctors which are studied in those hospitals.

Abu Ubayd ac-Cuzcani wrote a poem about the ancient doctors. This poet is on the below.

"There was no medicine, Hippocrates found.

He was dead, Galenus resurrected.

Blind, Huneyn bin Ishaq opened his eyes.

Râzî collected his mess.

Ibn Sina completed his deficiencies and matured."4

Abu Ubayd ac-Cuzcani

"Physicians and their works in Islamic civilization have an important place in the history of medicine. Although Muslim, Christian, Jewish, Magi or Ethnic Arab, Iranian, Turkish physicians, who lived in a wide Islamic geography and wrote their works in Arabic, made some provisions about their nationality, it is difficult to make a definite judgment since the understanding of the ummah was dominant in this period. There are hundreds of physicians enlightening the Eastern and Western worlds with their works in the Middle Ages." ${ }^{5}$ Here are some Mulsim Physicians who is studied about Medicine in classical Islamic World.

"Ali bin Rabben et-Tabari(d. After 861); el-Kindî (d. 873), Hunayn bin Ishaq (d.810-73); Abûbakir er-Râzî (d. 865-925), İbnü'l-Cezzâr (d. 979); Ali bin Abbâs el-Magi (d. 994), Ammâr bin Ali (d. 1010); Abu'l-Qasım Zahrâvî (d. 1013); Avicenna (980-1037); Ali bin Îsâ (d. 1038), İbn Zühr (ö. 1162); Maimonides (d.1204); ibnu'l-Baytâr (d. 1248) and there are many other physicians which they studied about medicine."6

And let's have a look about Turkish-Islamic Medicine. Turkish Medicine, in Historical Period seperates into four period;

"1-One and first of period of Turkish Medicine is the Peirod of Turkish Medicine Before the Islamic Medicine

2-Second period of Turkish Medicine is the Peirod of Turkish Medicine After the Islamic Medicine

3-Third period Turkish Medicine is the Peirod of Ottoman Turkish Medicine

\footnotetext{
${ }^{1}$ Bayat, History of Medicine, s. 209-210.

2 Bayat, History of Medicine, s. 210.

${ }^{3}$ Bayat, History of Medicine, s. 210.

${ }^{4}$ Bayat, History of Medicine, s. 215.

${ }^{5}$ Bayat, History of Medicine, s. 213.

${ }^{6}$ Bayat, History of Medicine, s. 213-230.
} 


\section{4-Fourth period of Turkish Medicine is Modern Turkish Medicine."1}

And from now on, we will try to tell about the second period because in this period Turkish physicians had kneaded the Turkish medicine knowledge and European medicine knowledge with Isamic medicine knowledge and they used this new medicine knowledge to built a new Turkish Islamic Medicine. And also they used this new medicine Turkish Islamic Medicine Knowledge in public service in the hospitals(Daru'sh-shifas) that Seljukies have built in Anatolia. Now let's look at these hospitals names. There are amny hospitals which Seljukies built in Anatolia.

"1-The Hospital of Mardin Nacmaddin Ilghazi

2-The Hospital of Kaysari Gavhar Nasiba Medical University and Hospital

\section{3-Syvas Izzaddin Qayqavus Hospital}

4- Divriği Turan Melek Hospital

5-Konya and Aksaray Hospitals

6- The Hospital of Çankırı Camaladdin Farruh

7-Tokat Muinuddin Scholomon Hospital

8-Kastamonu Ali bin Scholomon Hospital

\section{9-Amasya Anber Bin Abdullah Hospital"2}

After we have explained about Turkish-Islamic Medicine and Hospitals in Anatolia in Middle Ages. Now let's look at he treatment methods whcih are used in these hospitals. There are many classical treatment methods which Muslim Physicians used in these hospitals. Of course we can not explain all the methods. But we think two of these methods are very important. Let's look at what are they.

One of them is using water and music in treatment of psychological illnesses. This method is called water and music treatment.

"Each substance has its own vibration (frequency). Our body also has a vibration frequency. The disease is the disruption of cellular vibration in the body. For treatment, the disrupted vibration needs to be rearranged. The two compatible frequencies interact with each other to form a "resonance". In physics, resonance is the event that the first vibration initiates a second vibration that is compatible with it. In order to benefit from the healing effect of sound on the body and mind, it is aimed to rearrange the distorted body rhythm with the frequency of the voice played from the outside, to a sick body whose rhythm (vibration) is impaired or to an organ that is vibrated. In the Seljuk and Ottoman Darushshifas, the patients were made to listen the music which was played together with the sound of water. The sounds of water rising from the fountain -which has sprikler around it- in the middle of the courtyard provided the patients to relax and calm, thus increasing the healing effect of music. We know that it is used in Gavhar Nasiba Hospital Darushshifa and also this music and water treatment is used in Edirne Bajazid II. Darushshifa."

And let's have a look how was Europe were healing the persons who have phsycological illnesses while Turkish Pyhsycisians were healing these persons with music and sound of water in the Middle Ages. Micheal Foucault tells about the treatment methods of pyhsicians that they apply for treating the phsycological illnesses in Europe in the Middle Ages. Foucault tells about a table which shows a ship named the Ship of Madness People which is painted by Hieronymus Bosch. This table is about the madness people who are closed, externalized and marginalized to a ship and suddenly there had been a fire in the ship and madeness people and many other disabled people died by burning in that ship. And Hieronymus Bosch painted these people and has shown how these people died in that ship by burning. ${ }^{4}$

\footnotetext{
${ }^{1}$ Bayat, History of Medicine, s. 236-267.

2 Bayat, History of Medicine, s. 267-271.

${ }^{3}$ Sancak, Leyla; The Psychological Treatment Methods in the Turkish-Islamic Civilization and Comparison of Previous

Period Musical Therapy with Today's Music Therapy Practices, Unpublised Master Thesis, Nisantasi University,

Institute of Social Sciences, Supervisor: Assist. Prof. Dr. Sera Çetingök; İstanbul, 2019, s.34-35.

${ }^{4}$ Foucault, Micheal; History of Madness; translation: Mehmet Ali Kılıçbay; İstanbul, 2006; s. 23-85.
} 
And I leave the comparison to you about the treatment methods of Europe and Islamic Societies for healing phsycological illnesses in the Middle Ages.

And the other treatment method is healing pandemies by using thermae and healing hot waters and also by using hammams. In the Middle Ages there are many thermae and hammams in Anatolia. In the period of Turkey Seljuk State a hundreds of healing hot water resources nad thermae, which Homeros, Galenus and Strabon mentioned about them, have been used for healing the pandemic illnesses and many other new ones have been built. Let's look at the names of these thermae, hot water resources and hammams.

"According to one of the XIV. th century's writers, Omarî, there were more than 300 hot springs in Anatolia where the people went to find healing for various problems.

1-The most famous of these the thermal spring of Ilgın, which has been built by Alauddin Qayqubad,

2-Futher from this the thermal spring of Ankara Haimana and The Red Hammams;

3-Eskişehir; The Spring of Pergola;

4- Erzurum; The Spring Of llıca;

5-Kırşehir, The Spring of Karakurt(Blackwolf);

6-Kütahya, The Spring of Yoncall;

7-Havza, The Spring of Kızözü and Aslanagzi;

8-Ayash, The Spring of Karakaya."1

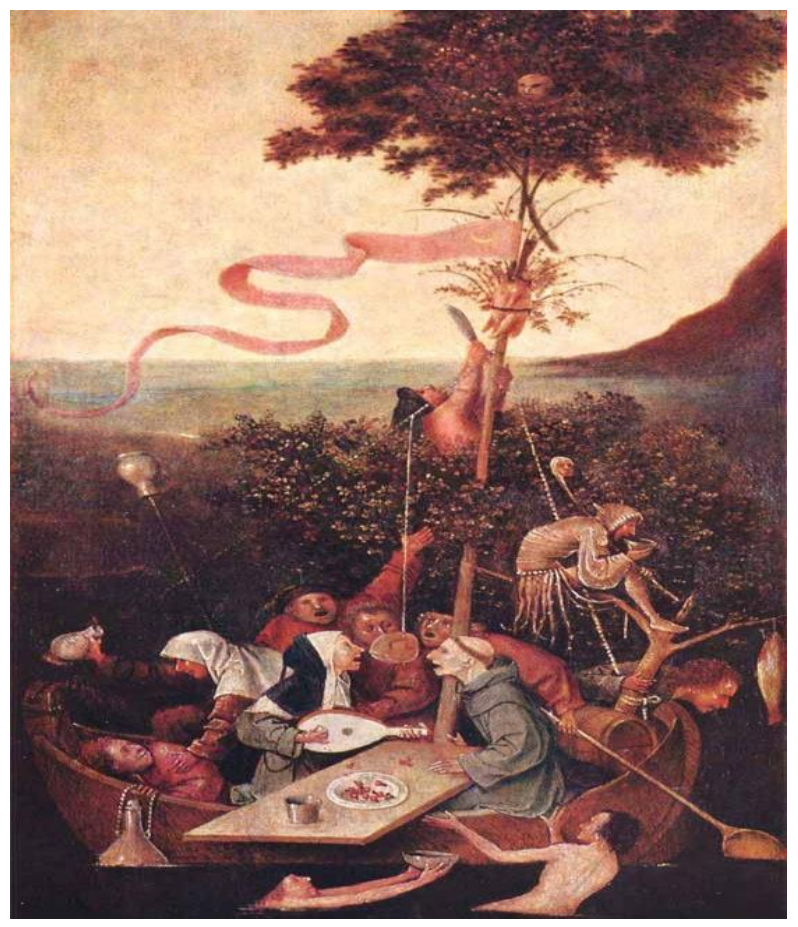

The Table of The Ship of Madness ${ }^{2}$ is in above.

${ }^{1}$ Bayat, History of Medicine, s. 267-268.

${ }^{2}$ https://tr.pinterest.com/pin/555772410260741282/?autologin=true, The Date of Access: 07.05.2020 
Turkish baths or hammams, which have been built by sultans and statesmen during the Seljuk period, have an important place among the Public Health Works. These hammams have like function for that societies like a Public Healthcare Centers. ${ }^{1}$

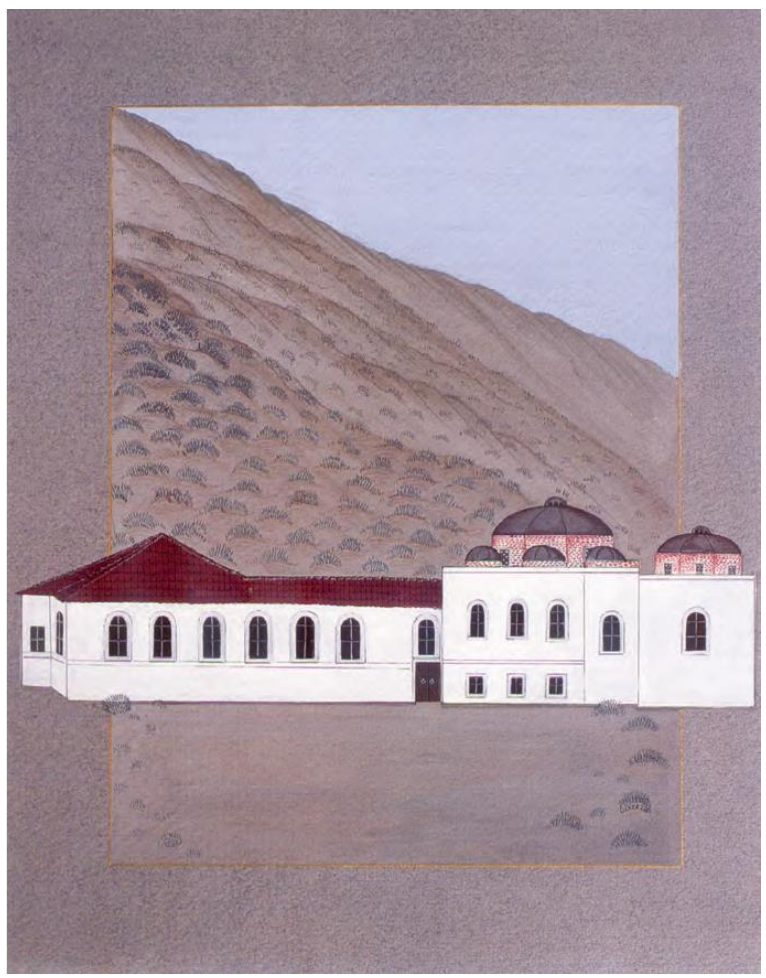

The Table of Spring of Konya llgın² is in above.

\section{Conclusion}

As a result; we can say about Turkish-Islamic Medicine Tradition; Muslim and Turkish doctors coped with or overcome with the pandemies in historical period with three methods;

1.Firtsly, being clean all the time and taking care of being cleanliness all the time both in terms of body cleanliness and cleanliness of food as Quranic verses and the hadiths said.

2.Secondly, applying qauarantine and isolation seriously when a Pandemic occurs in a place as it is said in Prophet's hadiths.

3.And thirdly using thermae and hot water resources and hammams for healing pandemies like plague and leprosy.

And as we have seen that there was big difference in the comprehension of healing and treating the illnesses especially pandemies in the Middle Ages between Europe and Islamic Counties. Let's come to today. Now today this difference in comprehension we have seen again in the pandemic of Choronavirus. Because Turkey is more succesfull than other countires because of this three healing and treatment methods and also because of this different comprehension.

\section{References}

[1] Ahmad b. Hanbal - Şuayib el-Arneut, Musnad; Müessesetu'r-risale, 1999.

\footnotetext{
${ }^{1}$ Bayat, History of Medicine, s. 268-269.

2 The table is painted by Ümit Erke. Look for the table Bayat, History of Medicine, s. 268.
} 
[2] Bayat, Ali Haydar; History of Medicine, Merkezefendi Traditional Medicine Association, İstanbul, 2010.

[3] Buhârî, Ebû Abdillâh Muhammed b. İsmâîl b. İbrâhîm Cu'fî Buhârî, Sahih-i Buhari, Kahire: Mustafa el-Babi elHalebi, 1953.

[4] Ebu Dâvud, Süleyman b. el-Eş'as, Sünenu Ebî Dâvud, İstanbul: Çağrı Yayınları, 1992.

[5] Foucault, Micheal; History of Madness; translation: Mehmet Ali Kilıçbay; İstanbul, 2006.

[6] Ibn Mace, Ebu Abdullah Muhammed bin Yezid er-Rebei el-Kazvini İbn Mace, Sünen, Delhi: Matbaatu'nNizami, 1905.

[7] İbn Kesîr, Ebü'l-Fidâ' İmâdüddîn İsmâîl b. Şihâbiddîn Ömer b. Kesir el-Kureyşi ed-Dımeşki. al-Bidâyah va'nnihâyah, Verification: Abdullah b. Abdulmuhsin et-Türki, Dâru'l- Hicre, 1998.

[8] İbn Khaldun, et-Tarif (The Souvenirs Between Scholarship and Politics), translator: Vecdi Akyüz, Dergah Publishers, İstanbul, 2017.

[9] İstek Emrah, "Great Plague in Europa and Religious Factor in Plague (The Sample of Vienna)"; The Journal of Historical Rese1, The Journal of Historical Researches(IJHR),Ankara, 2017, Volume:XXXVI, Number: 62.

[10] Müslim, Ebu'l-Hüseyin Müslimu'bnu'l-Haccac el-Kuşeyri en-Niysaburi, Sahihi Müslim, Verification: Muhammed Fuâd Abdülbâkî, Beyrut: Dâru Ihyai't-Türasi'l-Arabi, 1956.

[11] Sancak, Leyla; The Psychological Treatment Methods in the Turkish-Islamic Civilization and Comparison of Previous Period Musical Therapy with Today's Music Therapy Practices, Unpublised Master Thesis, Nisantasi University, Institute of Social Sciences, Supervisor: Assist. Prof. Dr. Sera Çetingök; İstanbul, 2019.

[12] The Qur'an English Meanings, Saheeh International, Jeddah, Abu'lqasım Publishing House,1997- al-Muntada al-Islamı- 2004.

[13] Tirmizî, Ebu İsa Muhammed bin İsa bin Sevre es-Sülemi et-Tirmizi, Sünen-i Tirmizi, Verification: Ahmad Mohammed Shakir, al-Maktabatul-Islamiyya, t.y.

[14] https://tr.pinterest.com/pin/555772410260741282/?autologin=true, The Date of Access: 07.05.2020. 